\title{
Supernovas: The Dialectic of Celebrity in Society
}

\author{
Lenn E. Goodman
}

Published online: 8 September 2010

(C) Springer Science+Business Media, LLC 2010

\begin{abstract}
Celebrity is manufactured in a society that has access to mass communications. But it still carries a mystique. Part of the appeal: romantic tales of discovery, fall, recovery and redemption.
\end{abstract}

Keywords Celebrity $\cdot$ Fame $\cdot$ Prurience $\cdot$ Fall and redemption $\cdot$ Being discovered $\cdot$ Character . Roles and expectations $\cdot$ Public personae

Many more people know about Andy Warhol's throwaway line - One day everyone will be world famous for fifteen minutes - than know much about his art. The remark Warhol first printed in a 1968 Stockholm museum catalogue and later repeated, revised, and self-parodied, is filled with ironies and paradoxes, markers of irony: If fame can come to anyone, why should it matter? How can fame today, so accessible, and vulnerable, allow anyone to stand out? What becomes of excellence, if P.R. can buy an image and a moment in the sun?

Art may be long, but memories are short, especially when ever new sensations crowd the attention span of an increasingly blasé public and sensate, segmented, flickering, and carnivorous media? If fame is disposable, isn't it also dispensable? Isn't a world where everyone is world famous also a world where fame is empty? And what about Warhol's lightly buried elitism, the half-suppressed snarl: By the time fame gets spread that thin, I at least will no longer want or need it. Is there something else, less fickle, that Warhol hoped to hold onto while the others stand in line and pass along what they've won at the sacrifice of wealth or dignity, their privacy, their children, their morals, or life itself?

\section{E. Goodman $(\bowtie)$}

Department of Philosophy, Vanderbilt University,

Furman Hall,

Nashville, TN 37240, USA

e-mail: Lenn.E.Goodman@vanderbilt.edu
Naturally, no one can be known by everyone, even for fifteen minutes. Only God can know and care about everyone and all things, everywhere and always. And that's only by not focusing on one individual to the exclusion of the rest. An ordinary mind needs selectivity: There's no memory without forgetting, no fame without erasure. Jackson Pollock can't be a household name without denying Tom Benton, and Benton can't find his niche without cutting loose from radical abstraction - just as the Impressionists unmoor themselves from Academic art, and Cezanne breaks free from Impressionism. Darwinism can't find its bottom without drowning Wallace, Spencer, Lamarck, even grandfather Erasmus. Christianity won't become a global franchise until it jettisons Judaism. If fame were ever really universal there'd be no need of experts, connoisseurs, specialists, memoirists, historians.

Yet we do covet the limelight. Americans aren't alone in that. What began in 2001 as Pop Idol on British television and morphed into American Idol in the United States became a worldwide enterprise, with offshoots in Australia, Latin America, Scandinavia, the Benelux countries, South Africa, the Balkans, India, Indonesia, West Africa, Armenia, New Zealand, Iceland, the Philippines, France, Germany, Singapore, Malaysia, Vietnam, Bulgaria, Greece, Portugal, the Arabic speaking countries, Estonia, and, yes, Kazakhstan. But the segmentation speaks volumes: a "world" bounded by cultural, linguistic, and commercial barriers. And atop Warhol's many-layered irony, another irony appears: Adulation may swing wildly into vicarious abuse, the tingle of pleasure at a bravura performance mingling with a certain schadenfreude as pretensions explode. Couch potatoes then thank the modesty or mediocrity that has kept them at home.

The democratic mythos that once pushed folk music onto the pop charts and prompted the hootenanny and promoted the sing-along, that set the girl next door onto a 
pedestal and idealized the ordinary guy, started making higher demands, pressing for recognition of all kinds of talent—not just step dancing or clogging or needlework but rap or hiphop, passion of any flavor.

There was paradox enough, to be sure, in the old Hollywood myth. Mickey Rooney, Judy Garland, or some passable surrogate, could say, with an epiphany in the eye and a light bulb overhead: "We've got enough talent here to put on a show!" But as dance numbers were rehearsed, costumes sewn, the old barn spruced up, and straitlaced backers charmed, there was always a tension, in movie dreams about local talent, between the poles of the ordinary and the spectacular. The same tension showed up in the Hollywood myth of the chance encounter, secular counterpart to old tales of fate and destiny: Chance was now the matchmaker, setting up pairs distinctive only in their homeyness, and yet remarkable, indeed unique, extraordinary - as if wish fulfillment and audience identification could turn base metal gold. Rub the magic lantern, and the genie will appear.

Today the polarity is sharper and the polarization more pronounced. Talent has become an ascriptive trait. Song is amplified to an electronic, ersatz scream or shriek, rhyme devours rhythm and swallows it, diction and all. The girls still scream, as their mothers did for Elvis, or the Beatles, and their grandmothers for Frank Sinatra,. But they no longer sing along. The words are hard to find. Terse and repetitious as they are, they're even harder to remember. The notes are not just tones but chords and sounds, nothing the boys can whistle while they work. And if the girls attempt a recap, they do it sotto voce, or into a mike or karaoke, while the boys, perhaps, back them on air guitar, or with the multitrack noises they've laid down in the mattress lined garage or basement that stands in for the old barn. There's not much participatory here. It's be a star or keep quiet and get off the stage.

The Muses run for cover, as the pornography of victimhood displaces the romance of the merely ordinary. Aladdin and his ilk were hapless. But today's celebrities rise not just from the ashes like Cinderella but from overt abuse. The Coal Miner's Daughter is a milder, gentler case. More typical today is Precious - or Stephen Hawking, rising from the depths. The one to watch is no longer merely poor or simple, or crippled, as in Dickens, but blind, addicted, a victim of incest or starvation, a survivor from the killing fields.

But there is a price to pay: If superstars are raised to the heights by myth, they will be subject to the laws of myth: supernova means explosion. Superheroes sell best if vulnerable. The old law of tragedy says stars must fall. If the persona is the product, the person is the victim, swallowed up in the persona. In myth, of course, only the symbol dies, perhaps ritually to be reborn. But in the old rituals that write the meaning of such myths, the victims really die, and only the rebirth is cosmic and symbolic.
Temple prostitution and human sacrifice were real. There really were virgins locked up in those temples, and the coupling of humans with beasts took place not just in hillside outposts but inside the temple walls and at the games.

Myth frames three stations for today's celebrities to pass through, chapters in the story that people, in the mass, expect to witness: discovery and rise, tragic fall, comeback and redemption.

\section{Discovery and Rise}

Romance trusts intuition but is not averse to irony. So it makes a good story to say that Lana Turner was discovered at 16 in Schwab's drugstore-much better than the narrative of her mother's early guidance of her working life, or her manufacture by the Hollywood studios' star making system. It was 1937, the height of the Depression. Jean Harlow had died, and Louis B. Mayer needed a new celluloid sex princess. Julia, as Lana was then known, was noticed by a talent spotter of Zeppo Marx's, not at Schwab's (despite the many hopefuls who later hung out at Schwab's soda fountain as long as it endured), but across the street at the Top Hat Café, drinking a Coke and cutting school. She got a part as an extra in a tight sweater, earning the nickname she hated ever after: "the Sweater Girl."

Signed at MGM for $\$ 100$ a week, Lana was finishing high school while the studio turned her into a teen heart throb. An ingenue in Love Finds Andy Hardy, a pin up in World War II, with a B-17 bearing her name, a femme fatale in The Postman always Rings Twice, finally recognized as a woman who could act, then a mother in Peyton Place, where plot twists seemed to play off the troubles of her private life - the stabbing death of her gangster boyfriend, Johnny Stompanato, slain by her daughter Cheryl Crane - as the coroner found, defending her mother's life. Later there were TV appearances in series like Falcon Crest.

Her ambition, Turner said, had been to have one husband and seven children, "but it turned out to be the other way around." A bit of grit helped her survive. She learned to stand up to the studios about her roles. And she was bornagain not long before she died in 1995, after 3-years' struggle with throat cancer. The religious conversion is hardly incidental. If a star's life is a script, there's got to be a plot. Only certain moves are open, and the players often come to live their parts. Death wants transfiguration. Social needs weigh in especially heavily for those who live in the public eye.

It was Norma Jean Baker, the woman who became Marilyn Monroe, who would be Jean Harlow's real successor. Her mother was a troubled film cutter at RKO; her father, unknown. She married at 16 to avoid returning to an orphanage but got a job in a munitions factory when 
her husband shipped out to the South Pacific in the Merchant Marine. The year was 1944. It was a photographer who "discovered" her. He was shooting pictures of women on the home front for Yank magazine and called her "a photographer's dream," soon sending her modeling jobs. Studying the work of Jean Harlow and Lana Turner, she divorced her husband and signed with Twentieth Century Fox at $\$ 125$ a week in 1946 .

The studying never sparked a legend. Even in a film, that couldn't amount to more than a montage of cut-in shots, an admiring face watching the screen, perhaps a headshot in the mirror, for a rather literal visual metaphor. Intelligence doesn't look like much on camera. After a series of bit parts and lesser roles, Marilyn made a mark in The Asphalt Jungle and All About Eve. She became a star in Niagara and proved her comedic talent in Gentlemen Prefer Blondes and How to Marry a Millionaire. At 27 she was voted best new actress of 1953 by Photoplay. The following January she married Joe DiMaggio. They honeymooned in Tokyo. But he seemed uncomfortable with the glamour girl image she projected when she made a side trip to Korea to give ten USO performances in 4 days for the American troops. The couple divorced before the year was out.

Moving to New York, Marilyn studied with Lee Strasberg, the godfather of method acting. She founded her own production company, making Bus Stop and (with Laurence Olivier co-starring and directing) The Prince and the Showgirl. Her performance opposite Jack Lemon and Tony Curtis in Some Like it Hot won her a Golden Globe. Strasberg said that of all the hundreds of actors he had worked with, she and Marlin Brando stood out above the rest. But her life ended badly.

Her marriage to Arthur Miller, who wrote The Misfits for her, ended in divorce, and she died in 1962 at 36, of an overdose of barbiturates. The Jean Louis dress she had worn in May, to sing a breathy public Happy Birthday to President Kennedy, was sold years later for over a million and a quarter dollars. Hugh Hefner bought the crypt beside hers, and there were eBay squabbles and court cases decades later over her personal effects and photographic licensing rights. She'd become the victim of the persona that made her famous. Even the shot of her skirt billowing up towards her face above a New York subway grate, in The Seven Year Itch, had become immortal. But the actress had not. Arthur Miller and Joe DiMaggio too were celebrities, superstars in their own right. So, of course, was John F. Kennedy, long rumored to have been among her lovers. But discovery is perhaps not quite the word to describe their rise.

John Kennedy, for his part, was backed politically by his father. Schooled at Choate and Harvard, he was mentored by a host of academics and intellectuals. He had traveled in Europe while his father was Ambassador to the Court of St
James. If one moment can be marked as the point at which he entered the public eye, it was the appearance of his senior honors thesis as a book, Why England Slept. Published with his father's help in 1940, the year of his graduation, it became a best seller. Kennedy dedicated his royalties on the 80,000 copies sold in the UK to the restoration of the Plymouth cemetery in England, bombed in the Battle of Britain. With his American proceeds he bought a Buick convertible.

As the title of the book suggests, it was a response to Churchill's While England Slept and looked sympathetically toward the Chamberlain government's appeasement policy, which Joseph Kennedy had supported. In it John argued that it would have been disastrous for Britain to engage earlier with the Nazi war machine. His later adventurism, interpersonal and international, egged on by his favored reading of Ian Fleming's James Bond books, fed the American appetite for a new hero.

Ike was an old hero, portrayed by the press as a bungler. Adlai was an egghead, or so his adversaries always saidand perhaps a bit pink. But Kennedy was an intellectual, or so we all believed, stout heart, war hero, patrician champion of the underdog, liberal long before that word had become a term of abuse, filled with imagination, married with class, reeking with style, surrounded by brilliant men, specialists in their fields, who did not intimidate him a bit. He was everything the country wanted to lead a new generation into a brilliant future.

Joe DiMaggio was in some ways a simpler case. A Hall of Famer in 1955, three times an MVP, an All Star in all his 13 seasons, the great Yankee slugger got 56 hits in a row, an all time record. In 1969 he was voted the greatest living player in the history of baseball. The son of a fisherman, he hated the smell of fish and said he'd do anything to escape cleaning his father's boat. His brother got him a chance to fill in as shortstop on the San Francisco Seals in 1932, and in the following year he made hits in 61 consecutive games, a record for the Pacific Coast League. That made DiMaggio himself a believer. "Getting a daily hit," he later said, "became more important to me than eating or sleeping." Despite a non-baseball knee injury, he was picked up by the Yankees for $\$ 25,000$; and the rest, as they say, is history.

DiMaggio was discovered by a baseball scout, and one could say he was a natural. But baseball talent has its own anatomy. In some other age the same man might have been a great hunter or warrior, if not struck down by a lucky bowshot from some enemy fighter or caught off guard by his prey. In baseball he led the Yankees to nine World Series championships. He was the first player to earn over $\$ 100,000$, and aficionados say he'd have hit far more home runs than he did if not for Yankee Stadium's deep left and center fields. He held loyal to Marilyn's memory and just days before her death sought to remarry her after she and 
Arthur Miller split. It was DiMaggio who claimed her body and arranged her funeral. He sent roses to her crypt three times a week for 20 years, never remarried, and refused to exploit his marriage to her.

Like every celebrity, DiMaggio's stature answered to the needs of his following. His role, like any human role, was a confluence of talents, conventions, moral strengths and weaknesses. His first marriage had ended in divorce, and his wife had taken custody of their child, his namesake. If DiMaggio's life did not end tragically, that was partly the result of circumstance. He might never have played in the majors had the Yankees not taken a chance on the healing of his knee. But his fortunes were also in part a product of his own decisions, confirming Heraclitus' ancient words, ethos anthropoi daimon, a person's character is his fortune.

Arthur Miller knew a fair amount about tragedy. Tragedy was his profession, and he understood that its dynamic does not confine itself to great figures in myth or in the past, or stay safely on the stage side of the proscenium arch. Miller actually was an egghead. But partly because of that he knew how to play to the expectations of an audience. He could take up the figure of the traveling salesman whose empty life Eudora Welty had sketched in "Death of a Traveling Salesman," and transform R. J. Bowman into Willy Loman, in Death of a Salesman, casting the common man as an archetypal tragic figure and painting America's economy into the role that Greek tragedy had reserved for fate.

Miller could sculpt the torsion lines of Greek tragedy in a close knit Italian longshoreman's family in Red Hook, Brooklyn, in A View from the Bridge, or in the crossed lives and love interests of men hunting mustangs to sell for dog food in The Misfits, the last film Marilyn Monroe and Clark Gable lived to make. He could stage An Enemy of the People with the theater audience seated aslant the assembly of Ibsen's fictive townspeople, so as to make the theater audience, too, complicit in condemning Dr Stockmann as a public enemy for trying to save the town's new baths from the toxic pollution of its tannery. In an equally heavy allegory, in The Crucible, he could make the Salem witch trials emblematic of the events of the Red Scare and the activities of the House Un-American Activities Committee, before which he too, as a result, would be called to testify.

Miller's discovery was not atypical for a writer. His family had been well to do. But his father lost their clothing store in the crash of 1929. Arthur, who had ridden in a limousine and enjoyed the summer home, delivered bread before school to help keep things afloat. He worked at menial jobs to pay his tuition at the University of Michigan but gave up his journalism major and switched to English when he won a \$250 prize for his play, No Villian, written in 6 days during Spring Break of his sophomore year, 1936.

Kenneth Rowe, Miller's teacher, had guided him, like all his students, through Aristotle's Poetics and taught him, by the analysis of great works for the stage, the structural elements of drama. The principles Rowe taught, later recorded in his vade mecum, Write that Play, were put to use by Miller as Rowe put him in touch with Broadway connections. The classic architecture stands out vividly in his later works. The same elements were also lived, more vividly perhaps, not just in the fall of his father's fortunes but in the loss and death of Marilyn, a tragedy that the outlines of Greek drama could never quite bring down to earth.

\section{Crash and Burn}

Virtue, of course, cannot guarantee happiness. A good life depends in part on good fortune: health, a modicum of skills, some measure of respite from the slings and arrows that beset every natural being. But virtue is the set of strengths that enable one-if catastrophe or cataclysm does not interfere - to breast the current and attain the goals that personal choices set before us and that our nature demands as conditions of survival-not to mention what our circumstances may seem to present as conditions of flourishing. The common wisdom of our peers and the special wisdom of worthy role models offer some guidance in identifying the relevant strengths and showing us how our acts and choices can undergird or undermine them.

Everyone can be tempted to take the line of least resistance. But celebrities face special pitfalls. Artists and intellectuals may succumb to the illusion that tracking or shaping mores and other values situates them somehow above the norms that others recognize. The adulation actors, politicians, athletes, explorers and adventurers enjoy, and the glitter heaped on by professional star-makers may dazzle not just their followers and attendants but their own eyes as well. Up on the heights, they may feel incapable of falling. Drugs, alcohol, and promiscuity may seem well earned rewards of prior sacrifices. And the sense of uniqueness that every human being enjoys makes stars especially vulnerable to a feelings of moral impunity and material immunity: rules are made for others; risks cannot touch me. Those twin illusions can be damning. Star quality itself can fade with age or be doused in an instant. The public is a mixed and turbulent body, always ready to snatch back what it has given and splash a former hero, whose hubris is discovered or perceived, with blame and shame and a gloating prurience that bitterly mocks the fresher prurience of adulation and emulous, admiring glances.

$\mathrm{Al}$ Gore, it was not long ago alleged, was seemingly able to persuade himself that his lost claims to a presidency narrowly missed, if fortified by environmental moralism, set him above the common herd. If buying carbon credits could offset the energy use of his 23,000 square foot home, why couldn't a 
Nobel Prize license betrayal of the marriage he once claimed was the model for Erich Segal's Love Story?

Eliot Spitzer, it seems, imagined that family wealth, past work for Robert Morgenthau in breaking the Gambino mafia family, and election as Governor of New York somehow privileged him above vulgar morals and allowed him repeatedly to betray his wife of over 20 years with a high priced prostitution ring that carried the revealing, flattering name, Emperor's Club. Clandestine wire transfers of tens in the tens of thousands of dollars to an offshore shell corporation, to funnel payment for his assignations, evidently didn't register in his inner moral counsels, since the appetites they served were private.

Michael Jackson, even now an idol to his fans, was afflicted with far costlier appetites. He paid \$17 million for Neverland in 1988 and spent a fortune filling it with art and toys to feed his fantasies. He refinanced it in 2007 for $\$ 45$ million, to support a lifestyle that left him increasingly impecunious, despite the immense earnings of his music. It took tens of millions of dollars to fend off the allegations he faced of sexually molesting boys. He died of acute propofol poisoning. Conrad Murray, the physician who prescribed the drug was contracted to receive $\$ 150,000$ monthly for that service.

Heath Ledger, the chess loving, award winning actor who played the psychopathic Joker, Batman's nemesis in The Dark Knight, had starring roles in Brokeback Mountain and other movies. He died at 28, from the combined effects, the medical examiner determined, of oxycodone, hydrocodone, diazepam, temazepam, alprazolam, and doxylamine. Just a little, just once, I'm different. Such are the lies that grease the chute to self-destruction. In moral terms none of us is quite as exceptional as we feel. The same holds true for the tolerances of the human body. And the two points, as many a classic student of human nature was not slow to note, are not unrelated.

\section{Up from the Lower Depths}

"Death," a sardonic colleague of mine used to say, "is nature's way of telling you to slow down." Not everyone who falls has a safety net, and not every dive bounces back into redemption, even for those who come out alive. Spitzer may have his contract with CNN, and OJ may escape the death penalty. Teddy Kennedy may continue in the Senate, revered to the end by a broad constituency. But he could never take up his dead brother's mantle. Chappaquiddick, in that sense, would haunt him to the last. O. J. Simpson might beat a murder wrap, but he would never again be the darling of car rental ads. The smiling college running back, the first NFL player to rush for more than 2,000 yards in a 14-game season, would lose his case in civil court, where the rules tilt less steeply in favor of the accused, his trial in steadier hands than the murder trial.

Saddled with a $\$ 33.5$ million wrongful death judgment that he could never pay, and dogged by the deaths he claimed had left no blood on his hands (although he had rehearsed the commando moves that brought them about, and was said to have confessed privately to murder), he was imprisoned finally, sentenced to at least 9 years, on charges of kidnaping and armed robbery, for using strong arm tactics in a dispute over sports memorabilia. Even his coyly titled book If I did It, seeking to rub some profit from the tarnish on a once shining image, had to be aborted and then privately published.

But not every fall is irrecoverable. Charles Colson, a key member of the Nixon team, known for his hard knuckle politics, pled guilty to obstruction of justice in the Watergate affair and served his sentence of 7 months. It was while facing arrest in connection with the coverup that he found Christ, helped by a born again friend and one of C. S. Lewis's worldly guidebooks to the maze of spirituality and a higher world. I say maze advisedly. Every culture has its well rooted hedges and openings. But it's cheap to suggest that each move in a well worn choreography must be insincere. Colson found a purpose for his life during his stay in prison and dedicated himself in the subsequent decades to prison reform and the spiritual reformation of prisoners. His name, acquiring a new patina through the story of his conversion, became a lifebuoy for convicts struggling for air in the sea cave where their own choices had trapped them.

Robert Downey Jr, once called America's most talented actor, son of the well known actor/director whose name he bore, fell hard on drug addiction, almost as if living the role that first won him acclaim. Finally clean, after years of hitting bottom, he starred in Iron Man and nearly took the Oscar for Best Supporting Actor for his role in Tropic Thunder, an award that Heath Ledger won for his nightmarish portrayal of the Joker. Downey's public was as fascinated with the happy ending of his comeback as with Ledger's fall. He went on to win a Golden Globe as Sherlock Holmes, although his movie contracts now typically hold back part of his salary, against the risk of an addictive relapse.

Like Colson, Downey found help in religion. He sampled Christian and Hare Krishna ideas but now calls himself a Jewish Buddhist. Religion here was not an opiate but an alternative, a source of moral and spiritual guidelines that were also lifelines leading toward the stable life and family commitments that Downey had seemed to hope for. Again like Colson, Downey found prison enlightening in a strange sense not unrelated to the old idea of a penitentiary: "you can't go from a \$2,000-a-night suite at La Mirage to a penitentiary and really understand it and come out a liberal," he said-but confessing that in Hollywood that isn't always the easiest thing to say. 
Angelina Jolie's case displays vividly the play of mirrors that makes a celebrity's fall and redemption as much a social as a personal, existential event. The handsome, award winning star, like Downey, was the child of actors (Jon Voight and Marcheline Bertrand). And, like Colson, she found herself, in part, by finding a cause. Her adolescence, far wilder than most, involved a serious loss of self-esteem, moshing with a live-in boy friend, self-laceration, and a fascination with death. After acting in many a movie, including five of her brother's student films, she won a Golden Globe for her work as Cornelia Wallace in a biopic about George Wallace, the Alabama governor, and went on to play the title role in Gia, a gritty film about a supermodel addicted to drugs and destroyed by AIDS. She gained international fame as Lara Croft in a film based on Tomb Raider, a videogame.

Although many of her films earned poor or mixed reviews, a number of them grossed in the hundreds of millions of dollars. Struck by the plight of refugees that she saw close up while making her first Tomb Raider movie in Cambodia, she has spent millions to help the displaced and dispossessed, and has traveled to Sierra Leone, Tanzania, back to Cambodia, and later to Thailand, Ecuador, Sudan, Sri Lanka, the North Caucasus, Chad, Haiti, India, and other countries, seeking to call attention to the plight of refugees and hoping to transform their image from that of pitiable outcasts to one of praiseworthy survivors. In her humanitarian travels she has pointedly shared the rough living conditions endured by other aid workers.

Besides monetary and publicity aid, she has lobbied for refugee interests and founded the National Center for Refugee and Immigrant Children, to provide free legal aid to children seeking asylum. After several divorces, she connected with another star, Brad Pitt, soon after his divorce from Jennifer Aniston. United by their six children, those to whom Angelina gave birth and those that they adopted, the couple seem to have found identities of their own by taking their minds off themselves and focusing on the desperate needs of others.

A final case study from the realm of politics. Robert Byrd, who died at 92, June 28, 2010, was the longest serving senator in American history, a member of the Senate for 51 years. This does not mean he was a great man. He was an active partisan of his West Virginia constituents, a champion of coal interests, and an effective deliverer of bacon, in the form of roads, bridges, dams, courthouses, and other federally funded projects. By his own estimate, he brought home to West Virginia "at least a billion dollars" in Federal funds.
Although he was his high school valedictorian and went to law school by night years later, Byrd grew up in poverty and had no college education. His identity was forged by his roles, no passive affair but the interplay of a strong willed individual with his social milieu: Byrd became the person he chose to be, responding to what he saw others wanting or expecting of him.

It was in the 1940s that Byrd organized and led a local klavern of the $\mathrm{Ku}$ Klux Klan, the much feared white supremacist organization, and it was a regional Klan grand dragon who first urged him to enter politics. Far from feeling used, Byrd was thrilled that "Someone important had recognized my abilities." He wanted, as he said, to be associated with the leading people of his surroundingsand he shared their fears and prejudices.

As times changed and Byrd met and joined forces with leaders from a wider world, his allegiances too would change. He voted for civil rights laws in 1957 and 1960. But he filibustered all night against the Civil Rights Act of 1964, championed by a more liberal Southern Democrat, Lyndon Johnson. He opposed the Voting Rights Act of 1965 and its renewal in 1970. Once a rival to Ted Kennedy, Byrd became his friend and ally, partly through their shared opposition to the Iraq war. He wept on learning that his fellow veteran senator had been diagnosed with a brain tumor. Byrd loved the Constitution and the Senate, its privileges and its place in protecting the people of the states. He would come, in time, to support ceding the Panama Canal, a cause he would never have favored as a younger man.

People like to use the word iconic to describe most anything they find familiar enough to think of as an old friend. That's part of what happens to celebrities: They become fixtures in our lives and memories, beloved by those they appeal to, irritations or obstacles to others. A celebrity doesn't need to be manufactured. Angelina Jolie has no publicist. She knows on her own how to play and work the mediahow to earn $\$ 14$ million for her foundation by selling the first pictures of her twins, rather than let the paparazzi shoot them. A celebrity's life is molded — if it is not destroyed - by an ongoing give and take between free actions, unruly passions, and the needs and aspirations, hopes and fears of a public that is itself self-governed or ill-governed, a mob, a market, a voter base, a fan base - the people.

Lenn E. Goodman Professor of Philosophy and Andrew W. Mellon Professor in the Humanities at Vanderbilt University is the author of Love Thy Neighbor as Thyself and of In Defense of Truth, Judaism, Human Rights \& Human Values, God of Abraham, On Justice, and most recently, Creation and Evolution. 